\title{
Behavior of wet precast beam column connections under progressive collapse scenario: an experimental study
}

\author{
Rohit B. Nimse · Digesh D. Joshi $\cdot$ Paresh V. Patel
}

Received: 7 August 2014/Accepted: 4 November 2014/Published online: 12 November 2014

(C) The Author(s) 2014. This article is published with open access at Springerlink.com

\begin{abstract}
Progressive collapse denotes a failure of a major portion of a structure that has been initiated by failure of a relatively small part of the structure such as failure of any vertical load carrying element (typically columns). Failure of large part of any structure will results into substantial loss of human lives and natural resources. Therefore, it is important to prevent progressive collapse which is also known as disproportionate collapse. Nowadays, there is an increasing trend toward construction of buildings using precast concrete. In precast concrete construction, all the components of structures are produced in controlled environment and they are being transported to the site. At site such individual components are connected appropriately. Connections are the most critical elements of any precast structure, because in past major collapse of precast structure took place because of connection failure. In this study, behavior of three different $1 / 3$ rd scaled wet precast beam column connections under progressive collapse scenario are studied and its performance is compared with monolithic connection. Precast connections are constructed by adopting different connection detailing at the junction by considering reinforced concrete corbel for two specimens and steel billet for one specimen. Performance of specimen is evaluated on the basis of ultimate load carrying capacity, maximum deflection and deflection measured along the span of the beam. From the results, it is
\end{abstract}

\author{
R. B. Nimse · D. D. Joshi $(\bowtie) \cdot$ P. V. Patel \\ Civil Engineering Department, Institute of Technology, Nirma \\ University, Ahmedabad 382481, Gujarat, India \\ e-mail: digesh.joshi@nirmauni.ac.in \\ R. B. Nimse \\ e-mail: 12MCLC26@nirmauni.ac.in \\ P. V. Patel \\ e-mail: paresh.patel@nirmauni.ac.in
}

observed that load carrying capacity and ductility of precast connections considered in this study are more than that of monolithic connections.

Keywords Progressive collapse scenario - Precast construction - Wet beam-column connection - RC corbel . Steel billet

\section{Introduction}

One of the major causes for failures of many high profile structures took place in last decade, around the world, is extreme loading effects generated due to hurricane, flood, earthquake, explosion, and terrorist attacks on buildings. This type of event imposes abnormal loading on the building structure. Generally members of building are not able to resist this type of abnormal loading and result into failure. One of the mechanisms of failure during such event is referred to as "Progressive Collapse". Progressive collapse is a situation where local failure of a primary structural component leads to the collapse of adjoining members, which in turn leads to spread of collapse. Progressive collapse is defined as "the spread of an initial local failure from element to element resulting in the collapse of an entire structure or a disproportionately large part of it" (GSA 2003). It is a chain reaction failure of building members to an extent disproportionate to the original localized damage (DoD 2013). Progressive collapse of building structures is initiated when one or more vertical load carrying members are seriously damaged or collapsed during any of the abnormal events. Once a local failure takes place the building's gravity load transfers to neighboring members in the structure. If these members are not properly designed to resist and redistribute the additional 
load that part of the structure fails. As a result, a substantial part of the structure may collapse, causing greater damage to the structure than the initial impact. Thus, it is necessary to provide sufficient redundancy, ductility and continuity, which helps structure to find alternate paths for load distribution during undesired failure event and thus to reduce progressive collapse.

Nowadays, there is an increasing trend toward construction of buildings using precast concrete. In precast concrete construction, all the components of structures are produced in controlled environment and they are transported to the site. At site such individual components are connected appropriately. This leads to speedy construction, reduced formwork and scaffolding, less requirement of skilled labors, reduced construction waste, better quality, and better surface finishing as compared to normal reinforced concrete construction. Because of such advantages the precast concrete construction is being adopted worldwide including India. In precast concrete construction, connections are the most critical elements of the structure, because in past major collapse of precast building took place because of connection failure. Therefore, it is very important to study the performance of connection between beam and column under a progressive collapse scenario.

The precast beam and column are connected either by mechanical means or by embedding reinforcements in preformed ducts which are subsequently filled by grouting. Accordingly the precast beam column junctions are known as dry or wet connections. In this study, behavior of different wet precast beam column connections is studied by performing the experiments and performance is compared with monolithic connection. Three $1 / 3$ rd scaled precast specimens with different connection detailing are constructed, which is part of six-storey building. Each specimen includes two span beams and three columns with removed middle column. Removed middle column represents column removal scenario, which in turn indicates progressive collapse situation. Response is measured in terms of ultimate load carrying capacity and deflection along the span of the beams under the application of monotonic vertical load at the location of removed central column. Load is applied with the help of hydraulic jack having capacity of $250 \mathrm{kN}$. From the study, it is observed that precast wet connections considered in this study are more ductile and able to resist more load as compared to monolithic connections.

\section{Literature survey}

Progressive collapse is not a new phenomenon in structural engineering community. Earliest example of progressive collapse goes back to partial collapse of Ronan Point apartment building in 1968. After the bombing of the
Murrah Federal Building in 1995 and collapse of Khobar Tower in 1996, considerable changes have been made in the design philosophy of the building structure to enhance progressive collapse resilience. But after the collapse of World Trade Center Towers due to terrorist attack in September 2001, many government authorities and local agencies have worked on developing guidelines for designing progressive collapse resistant structures. Among these guidelines, the U.S. General Service Administration (GSA 2003) and Unified Facilities Criteria UFC 4-023-03 published by Department of Defense (DoD 2013) provide detailed step-wise procedure and methodologies to resist the progressive collapse of building structures.

Marjanishvili (2004) discussed advantages, disadvantages, and limitations of various analysis procedure to investigate progressive collapse. Potential of nine-storey steel moment resisting building against progressive collapse was evaluated by performing linear static analysis, linear dynamic analysis, nonlinear static analysis, and nonlinear dynamic analysis (Marjanishvili and Agnew 2006). Effectiveness of different structural systems on progressive collapse resistance was also examined by researchers (Tsai and Lin 2008; Chen et al. 2012). Alashker et al. (2011) discussed various approximations considered during modeling for progressive collapse analysis and design.

Experimental investigations are equally important as they are helpful to validate the analytical findings. Kai and Li (2012) carried out experimental and analytical studies of progressive collapse resistance on four full scale beam column assemblies, which were part of eight-storey building. Behavior of steel and RC beam column assemblies with different seismic design and detailing under a progressive collapse scenario was studied (Sadek et al. 2011; Lew et al. 2013) through experimental and analytical investigations. Progressive collapse resistance of RC structure under column removal scenario was examined by many researchers (Yu and Tan 2013a, b; Su et al. 2009). Experimental studies were carried out on reduced scaled specimen such as beams and beam-column assemblies prepared with different design and detailing to observe the behavior under progressive collapse scenario. Progressive collapse resistance of precast concrete buildings was examined by Main et al. (2014) through experimental and analytical investigations on full scale test specimen. In their study, precast components were connected using steel link plates that were welded to steel angles embedded in precast beams and steel plates embedded in precast columns.

Many researchers have studied behavior of various types of precast beam column connections. Parastesh et al. (2014) developed new ductile moment resisting precast beam column connections. They have tested six full scale interior and exterior precast beam column connections under cyclic loading and compared their performance with 
monolithic connections. Seismic response of four full scale precast beam column connections subjected to cyclic loading was studied by Xue and Yang (2010) through experiments. Beam column connection include of exterior connection, interior connection, $\mathrm{T}$ connection and knee connections. Performance was evaluated in terms of stiffness degradation, energy dissipation capacity, displacement ductility, and failure mode.

Shariatmadar and Beydokhti (2014) tested three full scale precast beam to column connections by considering different detailing i.e., straight spliced, U-shaped spliced and U-shape spliced with steel plates within connection zone which was part of five-storey frame under reverse cyclic loading and compared its performance with monolithic connections. Choi et al. (2013) proposed design of precast beam column connections using steel connectors constructed by bolting steel tubes and steel plates fixed within precast components. This type of connection was suggested based on the results of cyclic load tests performed on five half scale interior precast beam column assemblies. Maya et al. (2013) recommended new beam column connection for precast construction using ultra high performance fiber reinforced concrete (UHPFRC) to achieve shorter splice length. They have tested four interior precast beam column assemblies subjected to cyclic loading.

Performance of reduced scaled and full scaled dry and wet precast exterior beam column connections were evaluated by conducting experiments under reversed cyclic loading (Vidjeapriya and Jaya 2012, 2013, 2014; Ertas et al. 2006; Joshi et al. 2005). Different means for precast beam column connections were adopted such as connection using dowel bar, dowel bar with cleat angles, cleat angles with single stiffener and double stiffener, tie rod and steel plates, use of cast in place concrete in beam and column, composite connection with welding, bolted connections, etc. Performance of precast connections was measured on the basis of strength, hysteretic behavior, energy dissipation capacity, ductility, and stiffness degradation and the same were compared with monolithic beam column connection.
Design handbooks are also available in which examples of different beam column connections are described (Elliot 2002; PCI 2010). These handbooks give design dimensions, capacity of different type of precast elements.

\section{Description of building}

The six-storey symmetrical building with rectangular plan is considered for the study. The building has 4 bays in longitudinal direction and 3 bays in transverse direction with $4 \mathrm{~m} \mathrm{c} / \mathrm{c}$ spacing in each direction. Overall plan dimensions of the building are $16 \mathrm{~m} \times 12 \mathrm{~m}$. A typical floor height of building is $3.2 \mathrm{~m}$ with height at bottom storey equal to $3.5 \mathrm{~m}$. The typical floor plan and elevation of the building is shown in Fig. 1.

\section{Design and detailing of specimen}

Perimeter frames of any building are exposed to highest risk of occurrence of any undesired event due to ease of accessibility. Therefore, the prototype of test specimens is assumed to be located at the middle of the perimeter frame in longer direction subjected to column loss at bottom storey as shown in Fig. 1. Dimensional analysis has been carried out to establish sizes of specimen. Three $1 / 3 \mathrm{rd}$ scaled precast specimens with different connection detailing and one 1/3rd scaled monolithic specimen are designed and tested under a column removal scenario. Each specimen contains two span beam and three columns with removed middle column. Removed middle column represents the progressive collapse scenario. Design and detailing of specimens having monolithic and precast connections are carried out by following the design provisions of relevant Indian Standards (IS: 456, 2000, IS: 1893, 2002, IS: 13920, 2003) and British Standards (BS: 8110-1, 1997).
Fig. 1 Typical floor plan and elevation of the building
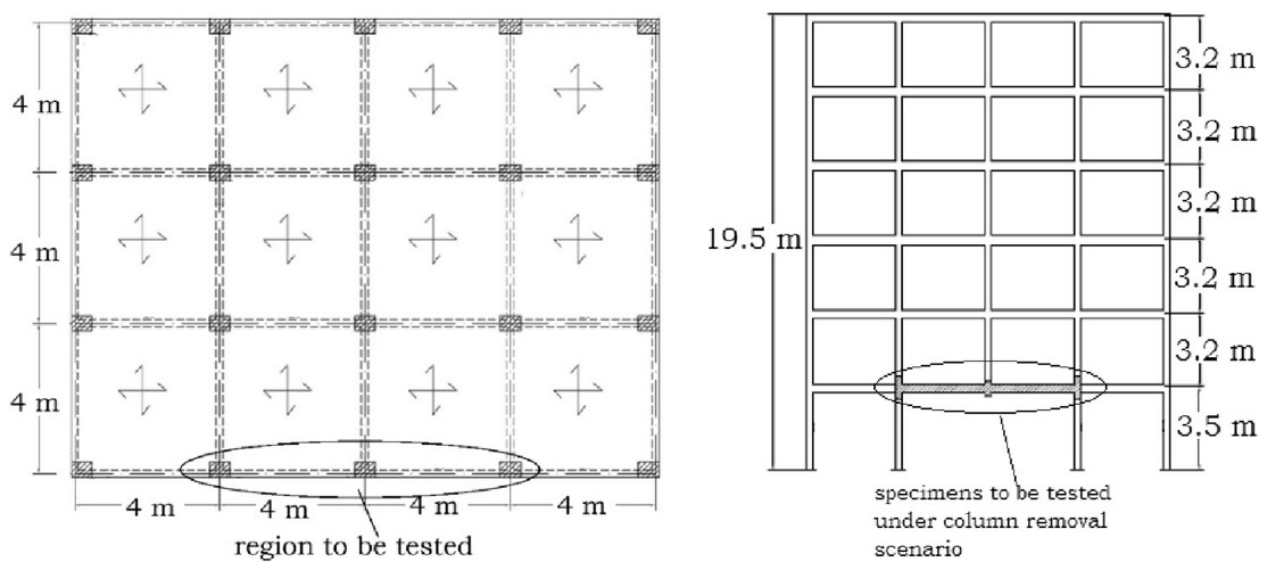


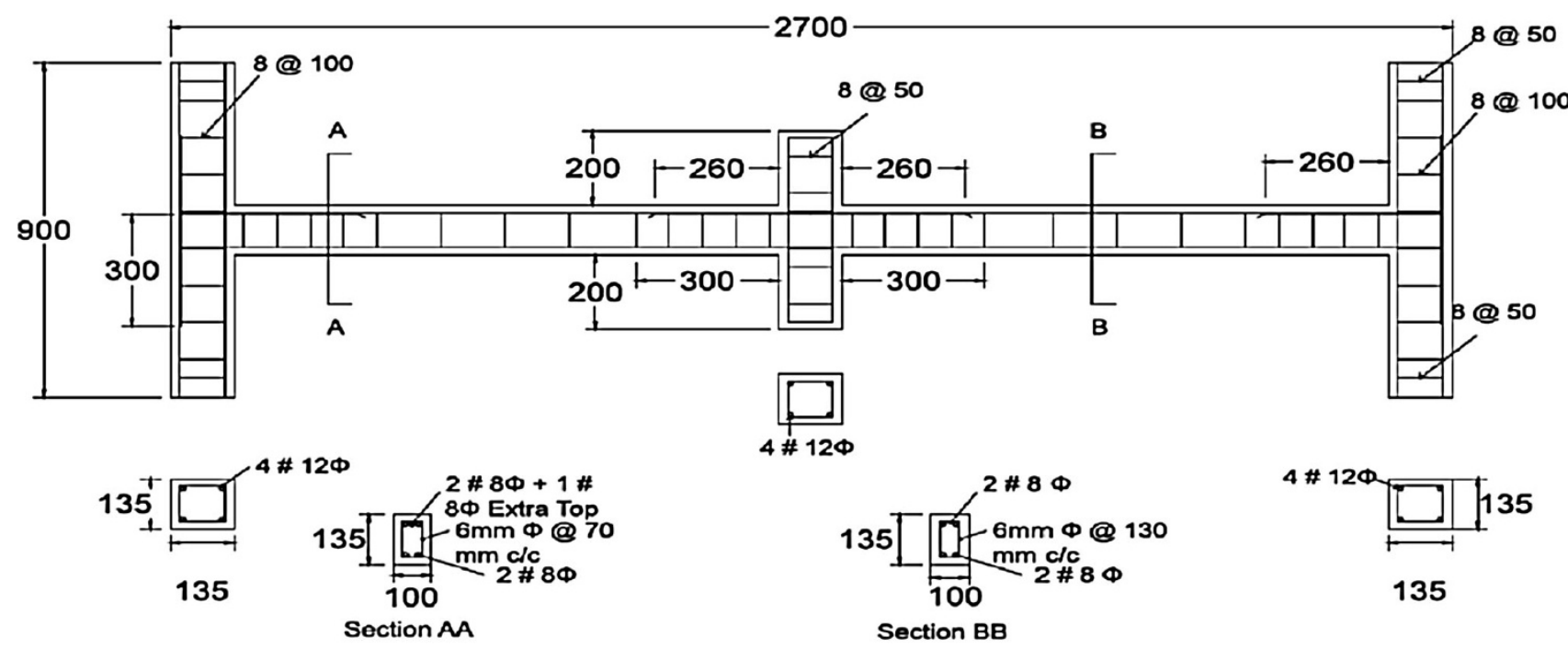

All dimensions are in $\mathrm{mm}$

Fig. 2 Detailing of specimen with monolithic connection (MC)

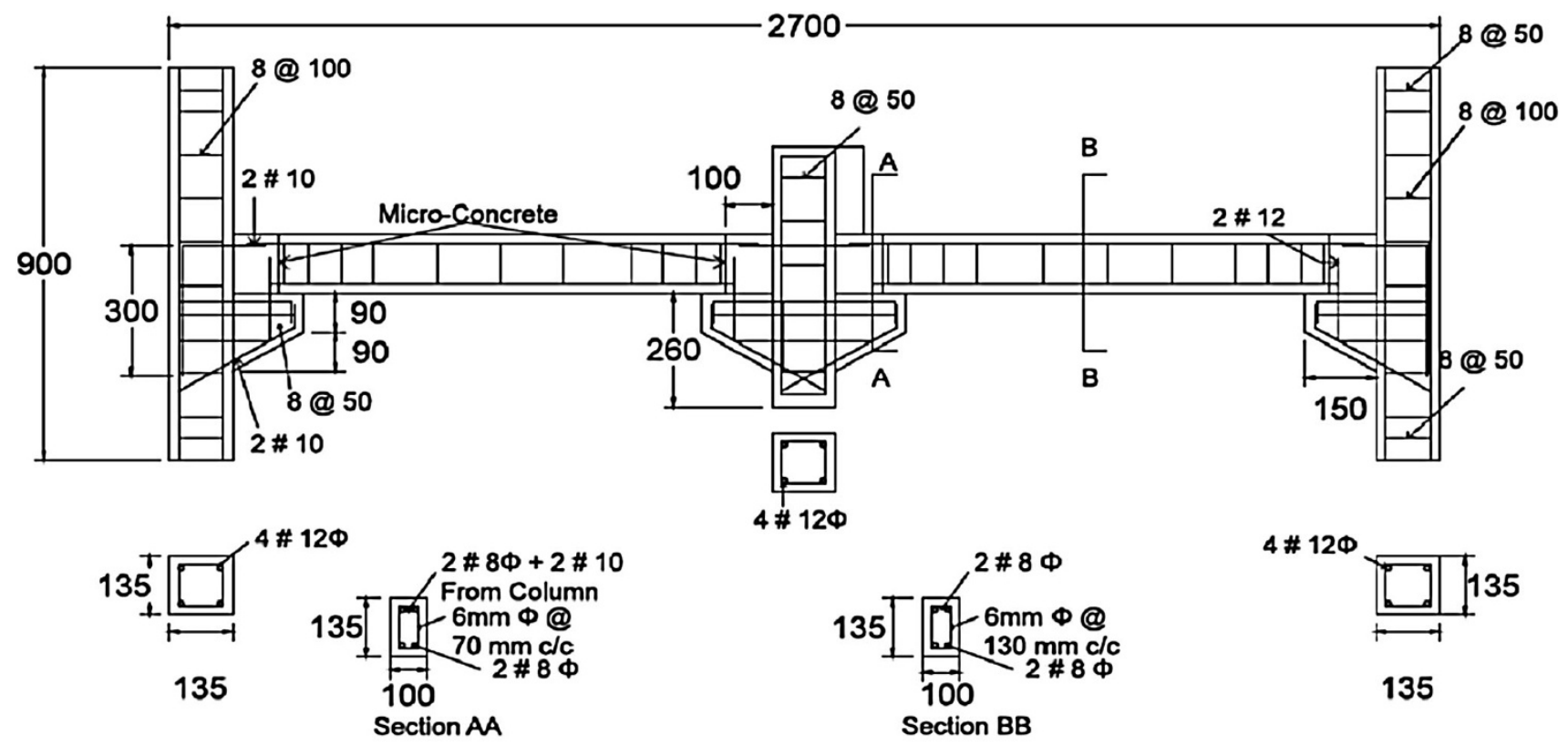

Fig. 3 Detailing of precast specimen with wet connection-1 (PC-CRW)

Two column stubs of $900 \mathrm{~mm}$ height and $135 \mathrm{~mm} \times$ $135 \mathrm{~mm}$ cross section are provided at both ends of specimen for providing sufficient anchorage for the longitudinal reinforcement. The beam is having cross section dimension equal to $100 \mathrm{~mm} \times 135 \mathrm{~mm}$. Closely spaced stirrups are provided at the beam ends near the junction. To avoid the crushing of concrete, closely spaced stirrups are also provided near the end of column stubs. Detailing of a specimen with monolithic connection and three specimens having different precast connections is shown in Figs. 2, 3, 4,5 .
In this study, three different $1 / 3$ rd scaled precast specimens with different wet connections are constructed and tested to study the behavior of wet connection during progressive collapse situations. In precast wet connection-1 (PC-CRW), continuity between beam and column is maintained by welding the top beam reinforcement bars protruding toward the column face with those projecting out from the column. The length of each reinforcement bar projecting from beam as well as column is $100 \mathrm{~mm}$ with the weld length of $80 \mathrm{~mm}$ within connection zone. The beam length resting on the corbel is kept as $50 \mathrm{~mm}$. Apart from 


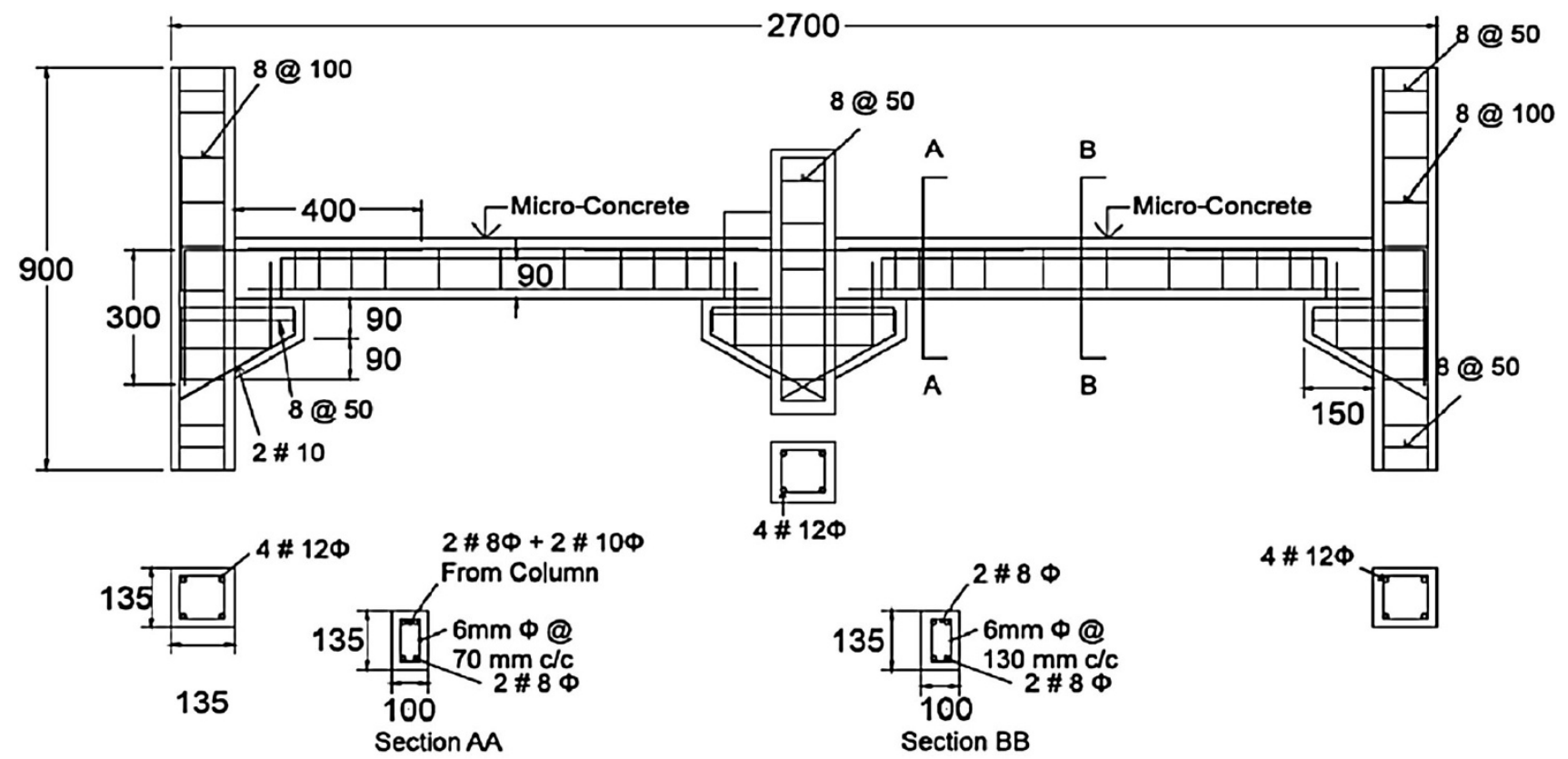

Fig. 4 Detailing of precast specimen with wet connection-2 (PC-CRS)

this two 12-mm- diameter bars with $50 \mathrm{~mm}$ length are projecting from the $\mathrm{RC}$ corbel into the connection zone. The empty spaces as shown in Fig. 6 are filled with cast in place micro concrete.

Precast beam is casted with normal cast in place concrete for only $90 \mathrm{~mm}$ portion from bottom face for precast wet connection-2 (PC-CRS). The remaining part of beam with $45 \mathrm{~mm}$ from top face is kept open as shown in Fig. 6, to provide continuity by inserting two 10 -mm-diameter reinforcement bars of length $400 \mathrm{~mm}$ projecting from column into the stirrups of beam in open area. The beam length resting on the corbel is kept $50 \mathrm{~mm}$. Apart from this two 12-mm-diameter bars with $50 \mathrm{~mm}$ length are projecting from the RC corbel into the connection zone. After inserting column reinforcement bars into the stirrups, the empty portion of $45 \mathrm{~mm}$ from top face of beam and connection region is filled with cast in place micro concrete. For precast wet connection-3 (PC-BRS) as shown in Fig. 6, RC corbel is replaced with the steel billet by keeping all other details are as it is. A hollow rectangular steel section is used as steel billet. The photographs of typical connection details for all the precast specimens are shown in Fig. 6.

\section{Casting of specimens}

M25 grade of concrete and $\mathrm{Fe} 415$ grade of steel are used for casting of all specimens. Material test includes testing of compressive strength of concrete. Because of reduced scale and small cross section aggregate of size $10 \mathrm{~mm}$ are used.
Specific gravity of coarse aggregates $(10 \mathrm{~mm})$ and fine aggregate used for casting are 2.78 and 2.54 , respectively. Sand of Zone II and OPC 53 grade cement are used. Mix design of concrete is carried out according to IS: 10262 (2009). Concrete mix proportion of various ingredients used for casting of RC specimen is shown in Table 1.

Total four batches of concrete mix are produced for casting during experimental program. From each batch three cubes of $150 \mathrm{~mm} \times 150 \mathrm{~mm} \times 150 \mathrm{~mm}$ are prepared to know the compressive strength of concrete. Strength of concrete is confirmed by cubes which are tested after 28 days of curing period. Average compressive strength of $32.99 \mathrm{MPa}$ is achieved. Wooden formwork is used for casting of precast specimen.

\section{Test set-up and procedure}

Schematic diagram of test set-up is shown in Fig. 7. To simulate exact condition as in prototype building, two triangle frames are fabricated to prevent horizontal movement of end of column. These triangle frames are attached with the existing loading frame that enables them to transfer the load from column to existing loading frame. End columns are restrained vertically by providing equal reactive force through hydraulic jack at bottom of it. Total four Caps are fabricated, two caps are attached with triangle frame and two caps are placed on hydraulic jack, to maintain the position of column. After erection of triangle frame, bottom hydraulic jack and caps, specimen is placed in the position. 


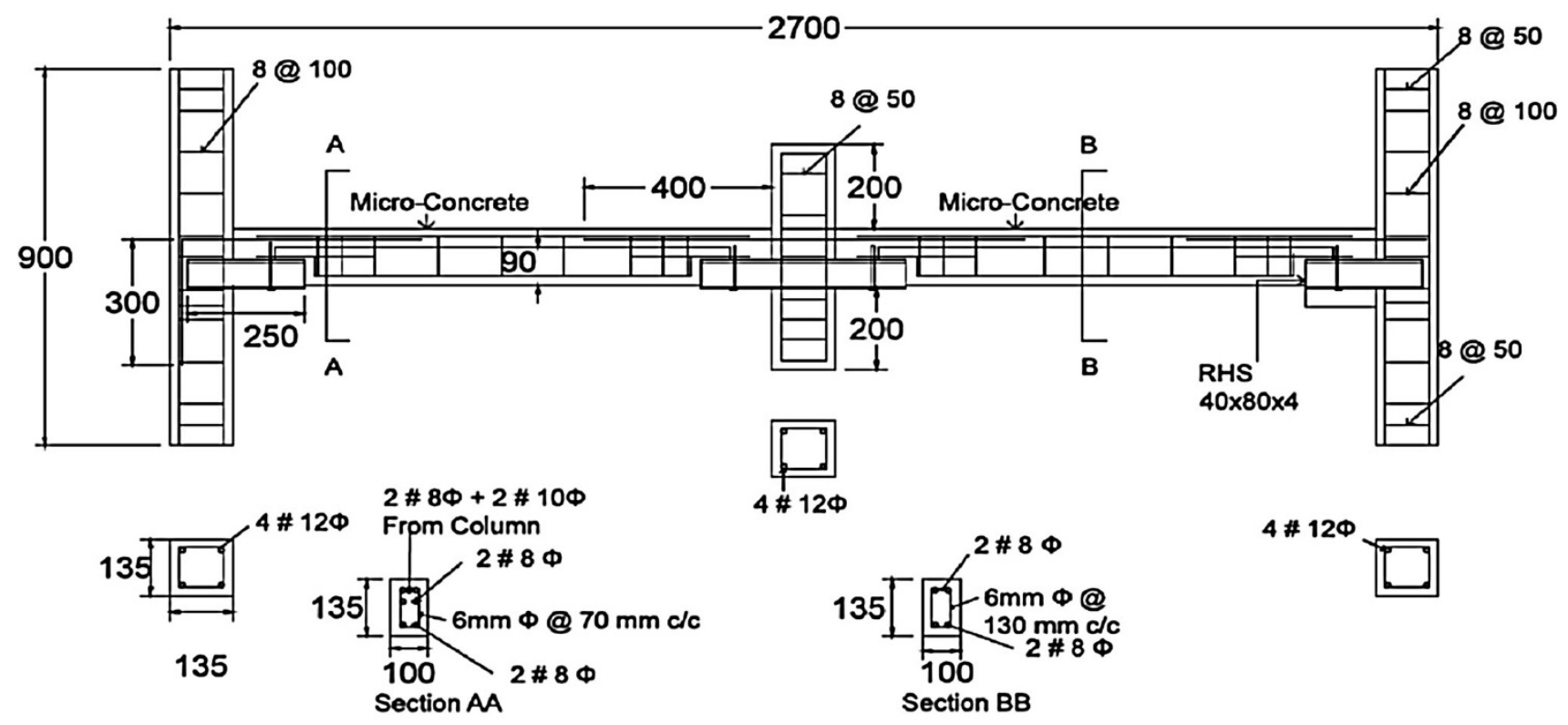

All dimensions are in $\mathrm{mm}$

Fig. 5 Detailing of precast specimen with wet connection-3 (PC-BRS)

Fig. 6 Detailing at precast beam column connection a $\mathrm{PC}$ CRW b PC-CRS c PC-BRS
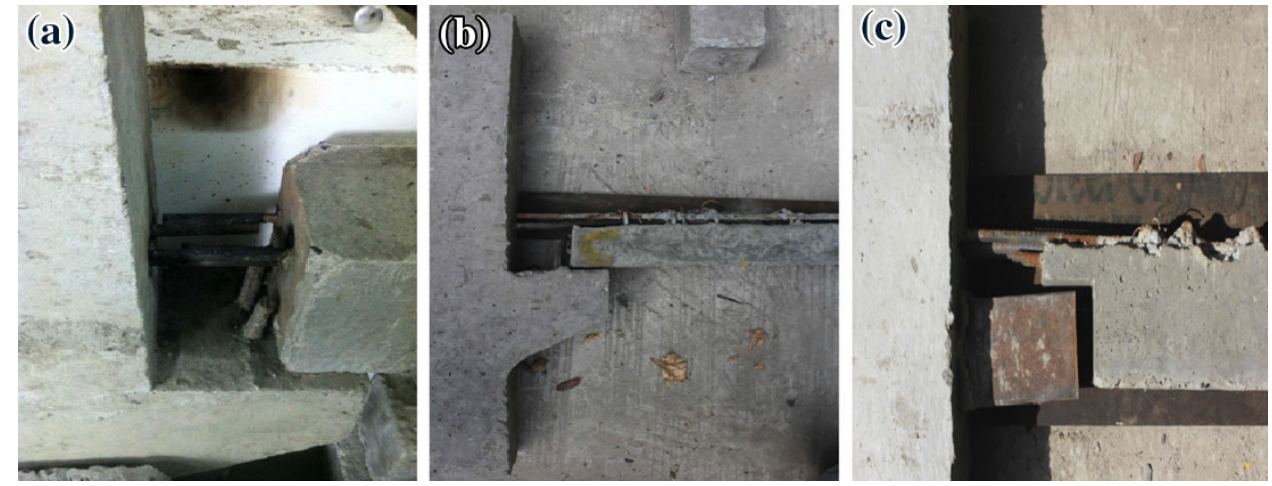

Table 1 Concrete mix proportion

\begin{tabular}{lllll}
\hline Concrete grade & Cement & $\begin{array}{l}\text { Fine } \\
\text { aggregate }\end{array}$ & $\begin{array}{l}\text { Course } \\
\text { aggregate }\end{array}$ & W/C ratio \\
\hline $\begin{array}{l}\text { M-25 } \\
\text { Ingredient }\left(\mathrm{kg} / \mathrm{m}^{3}\right)\end{array}$ & 1 & 3.14 & 2.71 & 0.45 \\
$\mathrm{M}-25$ & 332 & 1,045 & 900 & 150 \\
\hline
\end{tabular}

Leveling of the test specimen is ensured to avoid development of cracks due to level difference. The gap between hydraulic jack and top of the specimen is filled with spacer plates. The Load is applied at the top of the removed middle column with the help of hydraulic jack of capacity $250 \mathrm{kN}$ till the complete failure of specimen takes place. The response of specimen under column removal scenario is observed in terms of vertical deflection measured with the help of four dials gauges and one LVDT.

\section{Instrumentation}

The arrangement of the instrumentation system consists of two different parts: (i) four dial gauges placed along the span of the beam to measure the vertical deflection at different locations and (ii) one linear variable differential transducer (LVDT) at center to measure vertical deflection at location of removed middle column. A schematic layout of instrumentation is shown in Fig. 8.

\section{Results and discussion}

To study the behavior of beam column connections for progressive collapse resistance, three different wet precast connections and one monolithic connection are tested. Different connection detailing using $\mathrm{RC}$ corbel and steel 
Fig. 7 Schematic diagram of test set-up
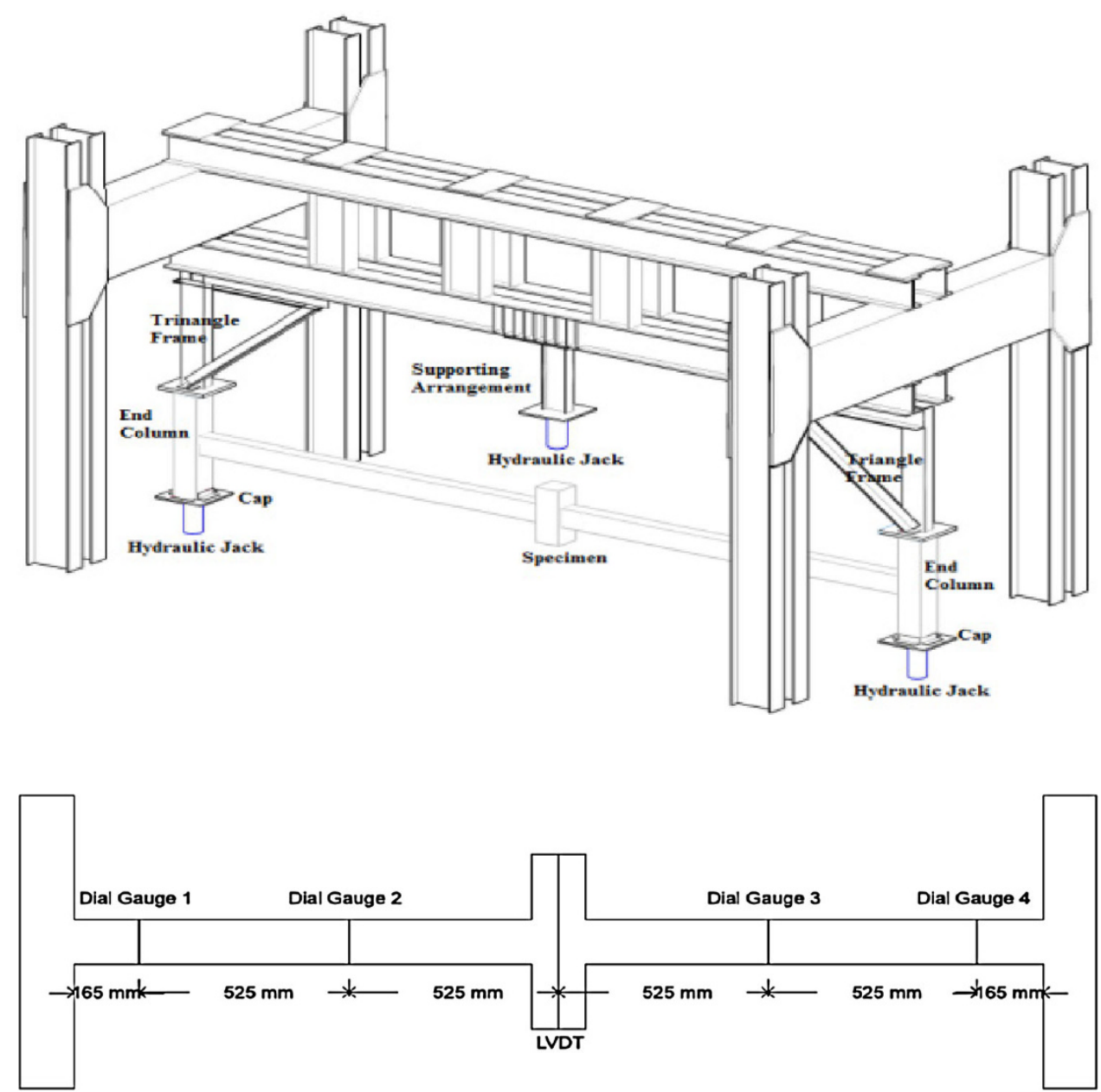

Fig. 8 Layout of Instrumentation-location of dial gauges and LVDT billet is adopted to construct precast connections. To accommodate the specimen in available testing facility, reduced 1/3rd scaled specimens are constructed. Each specimen contains two beam spans and three columns, with removed middle column. Removed middle column represent progressive collapse scenario. Behavior of connections is observed by applying load at the location of removed middle column with the help of hydraulic jack of capacity $250 \mathrm{kN}$. Result in terms of vertical deflection along the span of beam and ultimate load resistance capacity are measured. Deflections at five different locations are measured with the help of LVDT (at center) and dial gauges as shown in Fig. 8. Deflection measured along the span of beam for monolithic and precast specimens at different load is presented in Fig. 9. These curves indicate deflected shape of precast specimen at different loading. The graph of load versus central deflection for all the four specimens is shown in Fig. 10.

Result presented in Fig. 9 shows that initially beam column assembly behaves as fixed beam and deflection at junction is very less. The change in curve pattern revealed that, beam column connection at both the extreme ends gradually losses fixity as load is increased. It is also observed that beam behaves in almost symmetrical manner with maximum displacement at location of removed column. For monolithic connection, the first crack is observed at a load of $12 \mathrm{kN}$ on the top face of left beam near the location of removed middle column as shown in Fig. 11. As crack is initiated near the left side of central column removal location, deflection of beam toward that side is slightly more as compared deflection observed at the other side. As load increases, cracks are continued to propagate till complete failure of specimen. Cracks are also developed on the top surface near both the extreme end beamcolumn junction as shown in Fig. 11. Specimen is failed at load of $24 \mathrm{kN}$ and is not capable to resist further load but deflection is still continued. After maximum load carrying capacity is reached, dial gauges and LVDT are removed and deflection is measured with the help of scale.

Specimen with precast wet connection-1 (PC-CRW) is failed at load of $28 \mathrm{kN}$. The first crack is observed at the load of $10 \mathrm{kN}$ in the region filled with micro concrete at the junctions as shown in Fig. 12. This crack initiated exactly at the interface of micro concrete and normal concrete, 
(a)

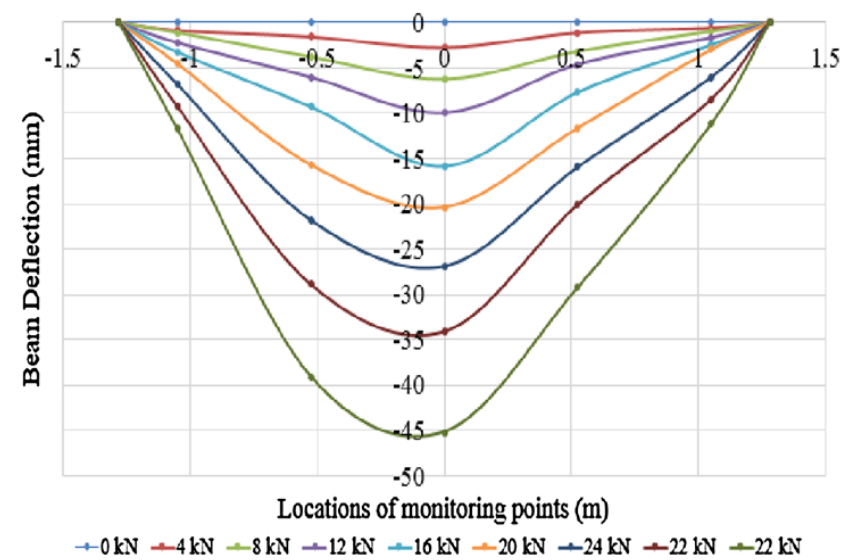

(c)

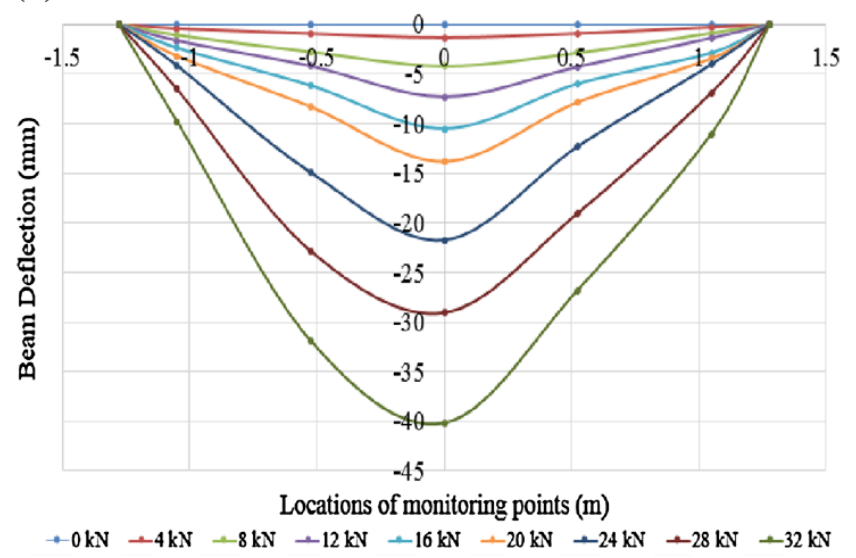

(b) Precast Wet Connection-1 (PC-CRW)

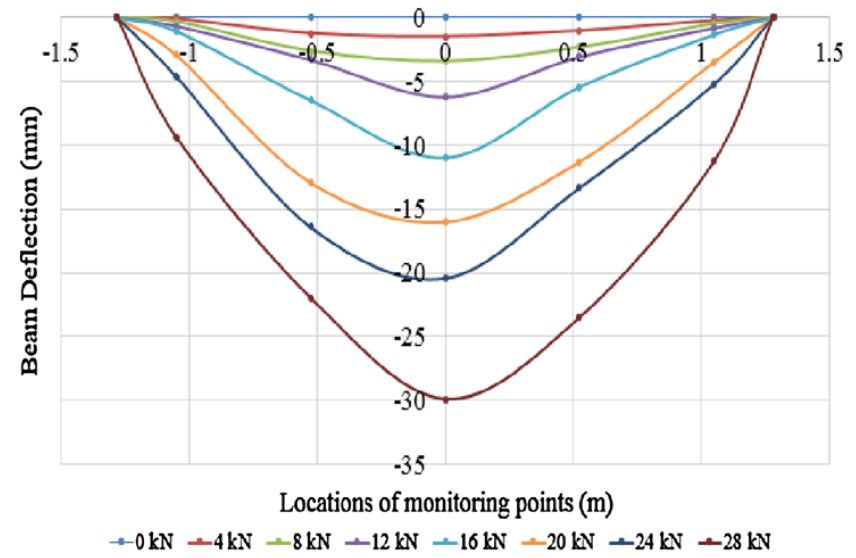

(d)

Precast Wet Connection-3 (PC-BRS)

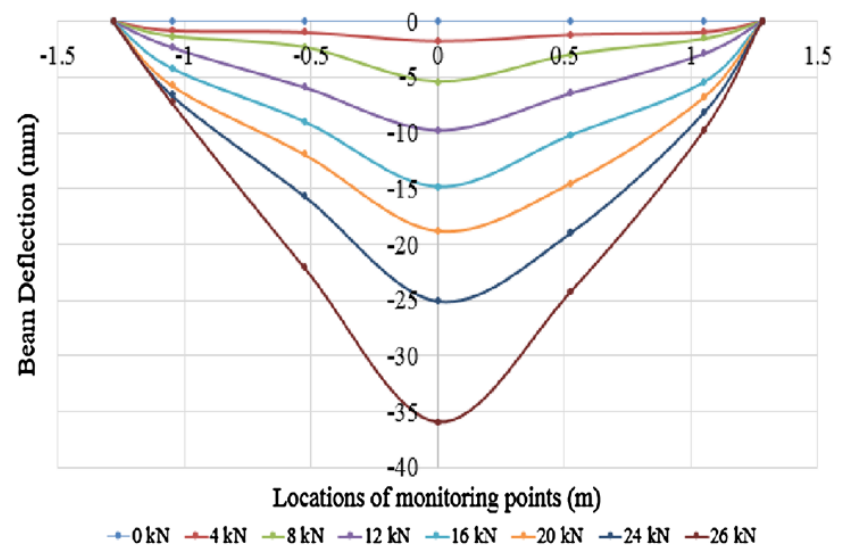

Fig. 9 Deflection along the span of the beam a MC b PC-CRW c PC-CRS d PC-BRS

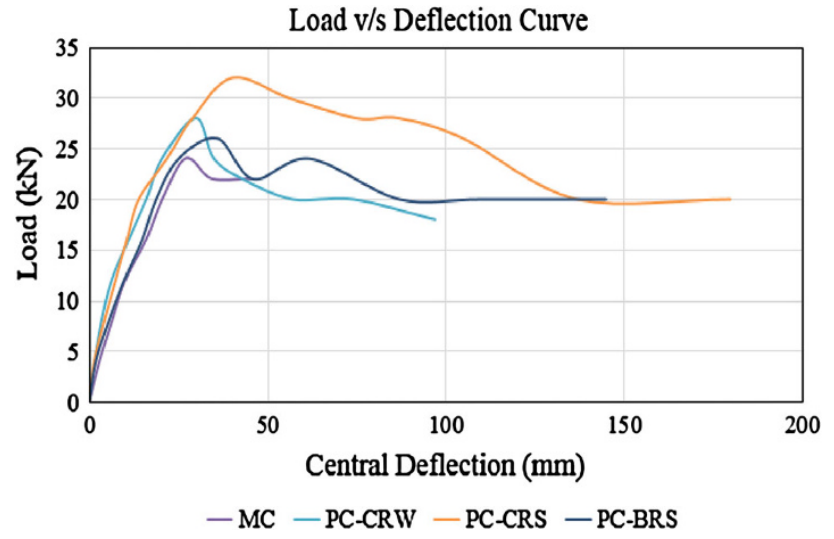

Fig. 10 Load versus deflection curve

which indicated that proper bonding between micro concrete and normal concrete is not achieved. This cracks are diagonally propagated in upward direction. Few cracks are also observed on the top face of beam near the extreme right side beam column junction.
For specimen with precast wet connection-2 (PC-CRS), crack is initiated at load of $12 \mathrm{kN}$ on the side face of beam casted with microconcrete near the beam column junction. Specimen PC-CRS is capable to resist maximum load of $32 \mathrm{kN}$, as compared to all other specimen. Due to larger amount of forces transferred to column, end column stubs subjected to pull and push at top and bottom end, respectively. Because of this, cracks are also developed at the ends of column and later on spalling of concrete takes place near the top of column. The beam near the location of removed middle column exerts compressive forces at the top and tensile forces at bottom, which results into crushing of concrete at top surface and development of cracks at the bottom side of beam. The failure of specimen PC-CRS and formation of crack pattern are shown in Fig. 13.

The deflection of specimen with PC-BRS is quite symmetrical as compared to other specimens during initial phase of loading. The first crack is developed at the interface between beam and steel billet near the central beam column junction as shown in Fig. 14. With increase 

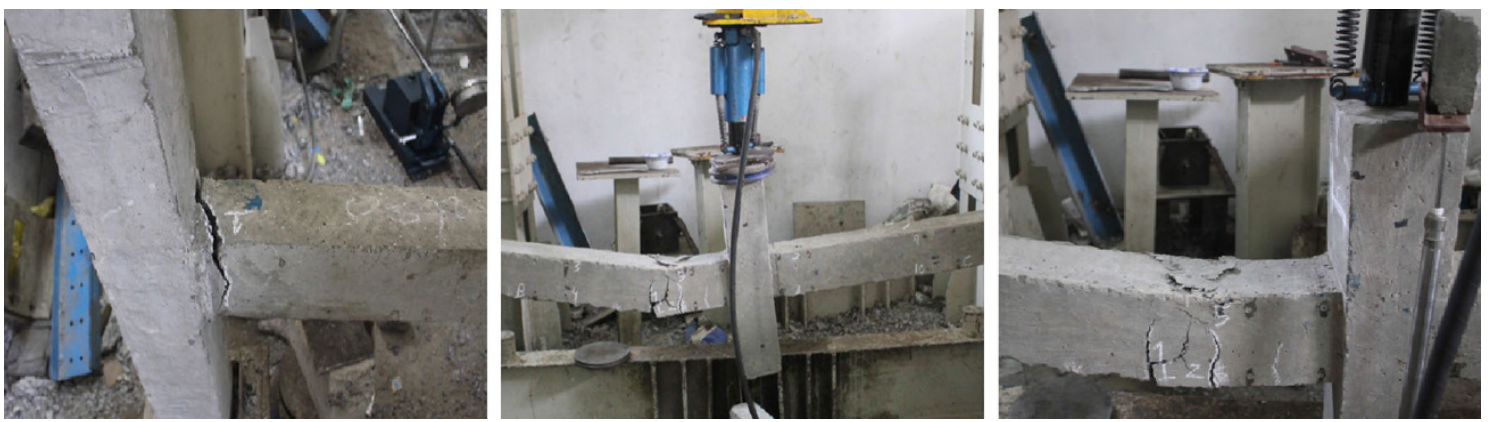

Fig. 11 Crack formation in specimen with monolithic connection (MC)
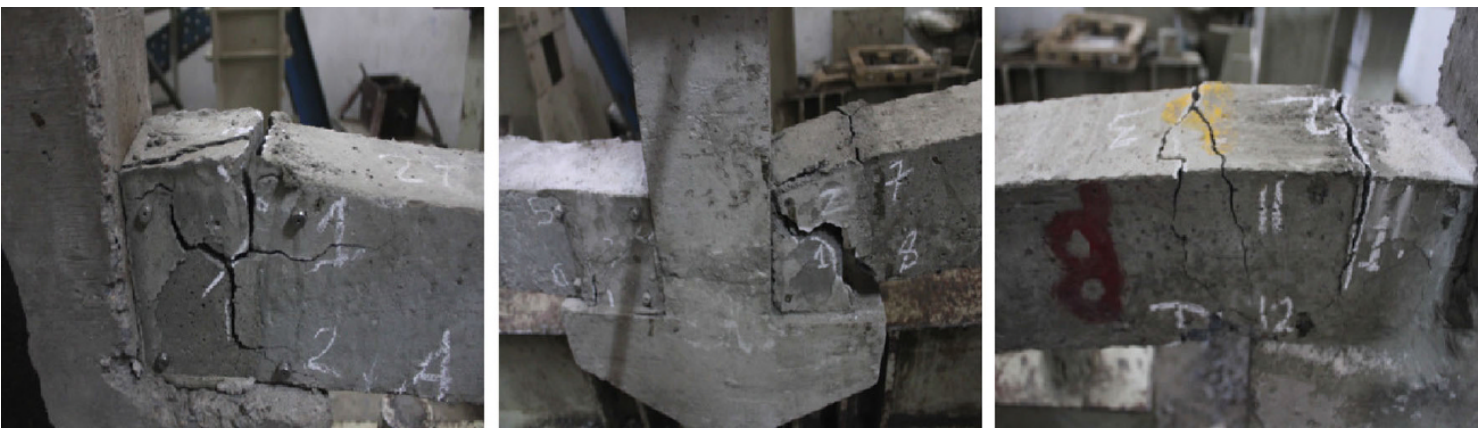

Fig. 12 Crack formation in specimen PC-CRW
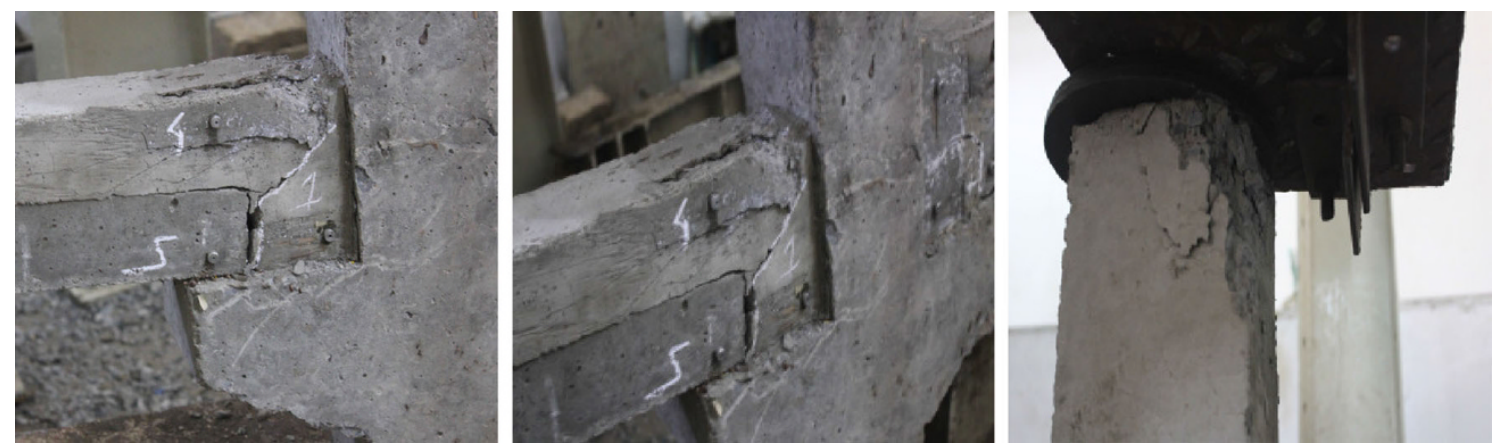

Fig. 13 Crack formation in specimen PC-CRS

in load, cracks at the left side of central junction are propagated, which results into unsymmetrical deflection of beam at higher load. The load carrying capacity of specimen PC-BRS is $26 \mathrm{kN}$, which is least among all the three precast specimen.

Comparison of maximum value of load and deflection corresponding to maximum load value for all the specimens is presented in Table 2.

\section{Conclusion}

Based on experimental study carried out, to investigate the behavior of different precast wet beam column connections during progressive collapse resistance, following conclusions are drawn.

- From the comparison of maximum load, it has been seen that precast connections are capable to resist more load as compared to monolithic connection. Load carrying capacity of specimen PC-CRW, PC-CRS, and PC-BRS are 16.67, 33.33, and $8.33 \%$ more, respectively, as compared to monolithic connection. It is observed that specimen PC-CRS is capable to resist more load as compared to all other precast connections as well as monolithic connection.

- From the failure pattern, it is observed that for all the precast specimen, failure initiated at the interface 

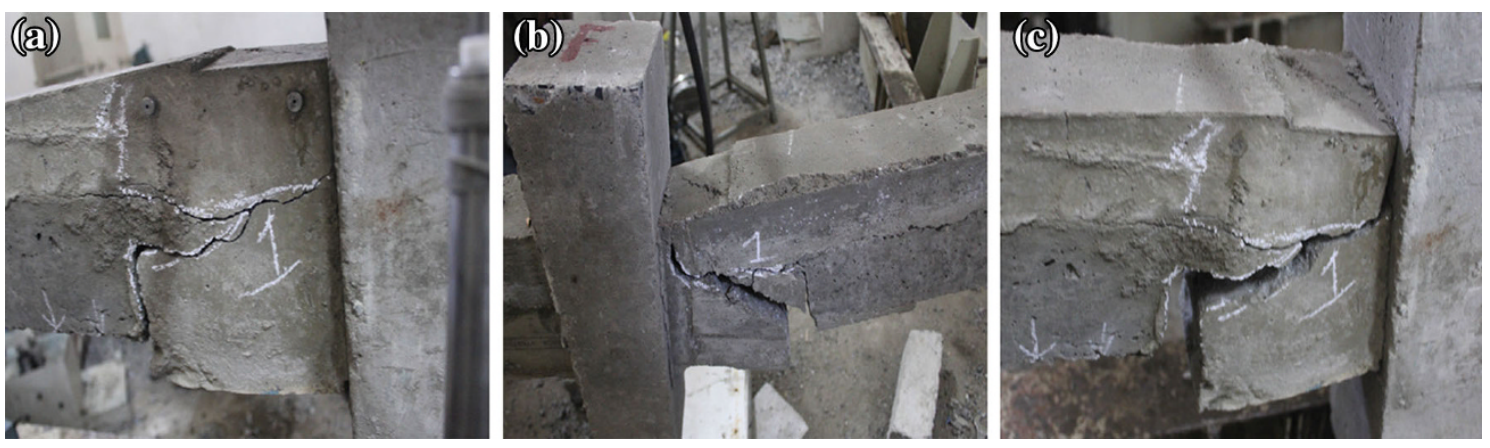

Fig. 14 Crack formation in specimen PC-BRS

Table 2 Comparison of maximum load and corresponding deflection

\begin{tabular}{lllll}
\hline $\begin{array}{l}\text { Specimen } \\
\text { type }\end{array}$ & $\begin{array}{l}\text { Maximum } \\
\text { load }(\mathrm{kN})\end{array}$ & $\begin{array}{l}\% \\
\text { increase } \\
\text { in load }\end{array}$ & $\begin{array}{l}\text { Deflection } \\
\text { corresponding } \\
\text { to maximum } \\
\text { load (mm) }\end{array}$ & $\begin{array}{l}\% \text { increase } \\
\text { in deflection }\end{array}$ \\
\hline MC & 24 & - & 26.91 & - \\
PC-CRW & 28 & 16.67 & 29.94 & 11.26 \\
PC-CRS & 32 & 33.33 & 40.22 & 49.46 \\
PC-BRS & 26 & 8.33 & 35.96 & 33.63 \\
\hline
\end{tabular}

between the region filled with cast in place microconcrete and normal concrete and further propagated. Failure at the interface revels un-bonding between microconcrete and normal concrete. The strength can be further enhanced by achieving proper bonding between two different materials.

- From the results of deflections, it is concluded that type of precast connections adopted in the study is more ductile as compared to monolithic connection. Deflection corresponding to maximum load is $11.26,49.46$, and $33.63 \%$ more for specimen PC-CRW, PC-CRS, and PC-BRS, respectively, as compared to monolithic connection.

- From the results of current study, it is observed that precast connections can be used as replacement of monolithic connections.

Open Access This article is distributed under the terms of the Creative Commons Attribution License which permits any use, distribution, and reproduction in any medium, provided the original author(s) and the source are credited.

\section{References}

Alashker Y, Li H, El-Tawil S (2011) Approximations in progressive collapse modeling. J Struct Eng 137:914-924

Bureau of British Standards (1997) Structural use of concrete Part-1 Code of practice for design and construction (BS 8110-1). London
Bureau of Indian Standards (2000) Indian standard code of practice for plain and reinforced concrete (IS: 456). New Delhi, India

Bureau of Indian Standards (2002) Criteria for earthquake resistant design of structures (IS: 1893), New Delhi, India

Bureau of Indian Standards (2003) Ductile detailing of reinforced concrete structures subjected to seismic forces: code of practice (IS: 13920). New Delhi, India

Bureau of Indian Standards (2009) Concrete mix proportioning guidelines (IS: 10262). New Delhi, India

Chen J, Peng W, Ma R, He M (2012) Strengthening of horizontal bracing on progressive collapse resistance of multi-storey steel moment frame. J Perform Constr Facil 26:720-724

Choi HK, Choi YC, Choi CS (2013) Development and testing of precast concrete beam-to-column connections. Eng Struct $56: 1820-1835$

Department of Defense (DoD) (2013) Design of buildings to resist the progressive collapse, Unified Facilities Criteria (UFC 4-023-03)

Elliot KS (2002) Precast concrete structures. Butterworth-Heinemann Publications, Great Britain

Ertas O, Ozden S, Ozturan T (2006) Ductile connections in precast concrete moment resisting frames. PCI J 5:2-12

Joshi MK, Murty CVR, Jaisingh MP (2005) Cyclic behaviour of precast RC connections. Indian Conc J 79:43-50

Kai Q, Li B (2012) Experimental and analytical assessment on RC interior beam-column subassemblages for progressive collapse. J Perform Constr Facil 26:576-589

Lew H, Main J, Robert S, Sadek F, Chiarito V (2013) Performance of steel moment connections under a column removal scenario. I: experiments. J Struct Eng 139:98-107

Main JA, Bao Y, Lew HS, Sadek F (2014) Robustness of precast concrete frames: experimental and computational studies. In: Proceedings of Structures Congress, ASCE, pp 2210-2220

Marjanishvili S (2004) Progressive analysis procedure for progressive collapse. J Perform Constr Facil 18:79-85

Marjanishvili S, Agnew E (2006) Comparison of various procedures for progressive collapse analysis. J Perform Constr Facil $20: 365-374$

Maya LF, Zanuy C, Albajar L, Lopez C, Portabella J (2013) Experimental assessment of connections for precast concrete frames using ultra high performance fibre reinforced concrete. Constr Build Mat 48:173-186

Parastesh H, Hajirasouliha I, Ramezani R (2014) A new ductile moment-resisting connection for precast concrete frames in seismic regions: an experimental investigation. Eng Struct 70:144-157

Precast/Prestressed Concrete Institute (2010) PCI design handbook: precast and prestressed concrete, 7 th edn. USA 
Sadek F, Main J, Lew H, Bao Y (2011) Testing and analysis of steel and concrete beam-column assemblies under a column removal scenario. J Struct Eng 137:881-892

Shariatmadar H, Beydokhti EZ (2014) An investigations of seismic response of precast concrete beam to column connections: experimental study. Asian J Civ Eng 15:41-59

Su Y, Tan Y, Song X (2009) Progressive collapse resistance of axially-restrained frame beams. ACI Struct J 106:600-607

Tsai MH, Lin BH (2008) Investigation of progressive collapse resistance and inelastic response for an earthquake-resistant RC building subjected to column failure. Eng Struct 30:3619-3628

U. S. General Service Administration (GSA) (2003) Progressive collapse analysis and design guidelines for new federal office buildings and major modernization projects. U. S. General Service Administration, USA

Vidjeapriya R, Jaya KP (2012) Experimental investigation of precast concrete beam-column wet connection under cyclic loading. In: Proc Struct Eng Conv (SEC), pp 287-292
Vidjeapriya R, Jaya KP (2013) Experimental study on two simple mechanical precast beam-column connections under reverse cyclic loading. J Perform Constr Facil 27:402-414

Vidjeapriya R, Jaya KP (2014) Behaviour of precast beam-column mechanical connections under cyclic loading. Asian J Civ Eng (Build Hous) 13:233-245

Xue W, Yang X (2010) Seismic tests of precast concrete, moment resisting frames and connections. PCI J 55:102-121

Yu J, Tan K (2013a) Experimental and numerical investigation on progressive collapse resistance of reinforced concrete beam column sub-assemblages. Eng Struct 55:90-106

Yu J, Tan K (2013b) Structural behavior of reinforced concrete beamcolumn sub-assemblages under a middle column removal scenario. J Struct Eng 139:233-250 